\title{
STRATIGRAFI DESA DURIAN GADIS SEBAGAI SUMBER PEMBELAJARAN SEJARAH DI SEKOLAH MENENGAH ATAS CANDRADIMUKA PALEMBANG
}

\author{
Oleh: Hamza Kurniawan* \\ *Sekolah Menengah Atas Negeri no.4 Palembang.
}

\begin{abstract}
ABSTRAK
Lapisan sejarah dan budaya di desa Durian Gadis memberikan informasi tentang sejarah kelokalan dan budaya yang menarik untuk diwariskan kepada generasi muda sekarang sebagai identitas bangsa. Rumusan masalah dalam penelitian ini adalah bagaimanakah stratigrafi desa Durian Gadis yang dapat dijadikan sebagai sumber pembelajaran sejarah di Sekolah Menengah Atas Candradimuka Palembang. Tujuan dalam penelitian ini adalah untuk mengetahui stratigrafi di desa Durian Gadis yang dapat dimanfaatkan sebagai sumber pembelajaran sejarah di sekolah menengah atas Candradimuka Palembang. Metode yang digunakan dalam penelitian ini adalah deskriptif kualitatif. Teknik pengumpulan data: dokumentasi, observasi dan wawancara mendalam. Pengujian data dalam penelitian ini menggunakan teknik triangulasi data. Hasil penelitian ini dianalisis dengan menggunakan model analisis interaktif. Hasil penelitian: desa Durian Gadis kaya akan data-data sejarah dari masa kerajaan Sriwijaya, kesultanan Palembang Darussalam, hingga masa-masa kolonial. Nilai sejarah stratigarfi desa Durian Gadis bisa dijadikan sebagai sumber pembelajaran sejarah di sekolah-sekolah.
\end{abstract}

Kata kunci: Situs, Stratigrafi, Sumber pembelajaran sejarah

\section{A. PENDAHULUAN}

Pendidikan adalah sutau proses dalam rangka mempengaruhi peserta didik, sehingga mampu menyesuaikan diri sebaik mungkin dengan lingkungannya. Dengan penyesuaian diri akan menimbulkan perubahan dalam dirinya yang memungkinkannya untuk berfungsi secara baik dan diterima didalam masyarakat. Menurut Sulo dalam Putri, (2015:123) mengemukakan bahwa jalur pendidikan sekolah dilaksanakan secara berjenjang yang terdiri atas jenjang pendidikan dasar, pendidikan menengah pertama, menengah atas dan pendidikan tinggi. Pendidikan menengah atas yang lamanya tiga tahun sesudah pendidikan menengah pertama. Pendidikan menengah atas merupakan sekolah lanjutan dan perluasan pendidikan menengah pertama serta persiapan untuk melanjutkan studi ke jenjang perguruan tinggi.

Dari beberapa mata pelajaran yang diberikan pada pendidikan menengah atas, salah satunya adalah mata pelajaran sejarah, dengan belajar sejarah biasanya mengajarkankan kepada siswa tentang nilainilai kejujuran, rasa tanggung jawab, rasa cinta pada sesama, saling menghargai, mau berjuang dan bekerja keras serta menanamkan nilai-nilai nasionalisme (semangat persatuan). Selain itu dengan belajar sejarah di sekolah, kita bisa mengetahui identitas bangsa ataupun manusia Indonesia di masa lalu, diharapkan akan dapat dipetik nilai-nilai positif yang begitu kaya (Kementerian Pendidikan Nasional, 2014:123-124).

Wilayah Sumatera Selatan dikenal juga sebagai daerah Batanghari Sembilan karena di wilayah ini terdapat sembilan sungai besar yang dapat dilayari sampai ke hulu, yaitu sungai Musi, Ogan, Komering, Lematang, Kelingi, Rawas, Batanghari Leko, Banyuasin dan Lalan. Sungai-sungai besar ini merupakan urat nadi kehidupan masyarakat sejak masa lampau berdasarkan bukti-bukti arkeologis yang tersebar di daerah aliran sungai (Rangkuti, 2007:1). 
Kabupaten Banyuasin adalah salah satu kabupaten di provinsi Sumatera Selatan. Kabupaten ini merupakan pemekaran dari kabupaten Musi Banyuasin yang terbentuk berdasarkan UU No. 6 Tahun 2002. Secara administratif kabupaten Banyuasin terdiri dari 19 kecamatan, yaitu: Air Salek, Banyuasin I, Banyuasin II, Banyuasin III, Betung, Makarti Jaya, Muara Padang, Muara Sugihan, Muara Telang, Pulau Rimau, Rambutan, Rantau Bayur, Sembawa, Suak Tapeh, Talang Kelapa, Tanjung Lago, Tungkal Ilir, Kumbang Padang, Marga Telang (Badan Pusat Statistik dan BAPPEDA kabupaten Banyuasin, 2012:17).

Desa Durian Gadis adalah sebuah desa yang berada di jalan lintas alternatif kabupaten yang menghubungkan kabupaten Banyuasin dengan kabupaten Ogan Komering llir. Pada desa Durian Gadis ini, peneliti mengadakan survei awal yang dilakukan di desa Durian Gadis kecamatan Rambutan kabupaten Banyuasin, tepatnya berada ditengah-tengah pemukiman warga. Pada pemukiman ini banyak ditemukan di permukaan tanah artefak-artefak yang berupa pecahan keramik-keramik Cina dan gerabah. Yang menarik pada temuan permukaan tersebut ditemukan pecahan keramik yang berasal pada masa dinasti Tang abad (abad 7-10 M), ini merupakan temuan tertua dari beberapa keramik Cina yang ditemukan. Temuan keramik tersebut didominasi oleh keramik Cina yang berasal dari Dinasti Ming (abad 14-17 M). Temuantemuan artefak tersebut mengindikasikan bahwa telah ada aktifitas manusia yang cukup lama di daerah tersebut, terbukti dengan temuan-temuan permukaan tersebut. Dari temuan permukaan pada survei awal dapat diperkirakan bahwa desa Durian Gadis telah dihuni dan ditempati oleh masyarakat zaman kerajaan Sriwijaya.

Temuan-temuan arkeologis di sepanjang aliran sungai-sungai besar (Batanghari Sembilan), memberikan informasi pada kita bahwa telah ada kegiatan masyarakat pada masa lampau di sepanjang aliran sungai tersebut. Sungai telah menjadi bagian tak terpisahkan bagi segala aktifitas manusia. Aktifitas sehari-hari masyarakat seperti memancing, kegiatankegiatan rumah tangga seperti mandi, mencuci, memasak tidak terlepas dari air. Selain itu sungai sebagai jalur transportasi untuk perdagangan produk hasil-hasil hutan, pertanian dan perkebunan kesemuanya menggunakan sungai sebagai infrastruktur pendukungnya. Kondisi demikian akan membentuk pola pemukiman masyarakat yang mengikuti daerah aliran sungai. Tidak mengherankan bila banyak ditemukan artefak-artefak sejarah yang mengandung nilai-nilai budaya hasil karya manusia tersimpan atau terpendam didalam tanah seiring dari kegiatan alami seperti erosi dan banjir yang terjadi secara berkala dan berlangsung dalam kurun waktu yang panjang ditemukan di sepanjang garis sungai.

Permasalahan ini melihat sejauh mana aktifitas masyarakat di desa Durian Gadis berdasarkan temuan permukaan pada survei awal tersebut. Selain itu peneliti tertarik untuk mengadakan penelitian ini, didasari oleh keinginan agar tersedianya materi pembelajaran sejarah lokal dalam pembelajaran sejarah. Sebab menurut peneliti pembelajaran sejarah yang ada saat ini, masih mengangkat tema-tema sejarah yang sangat nasional dan cakupannya yang sangat luas. Diadakannya penelitian ini, agar data-data sejarah lokal yang terdapat di masyarakat dapat dihimpun dan diawetkan kedalam sebuah tulisan ilmiah yang dapat dijadikan sebagai sumber pembelajara sejarah. Dengan harapan, setelah penelitian ini akan dapat mengedukasi peserta didik dan masyarakat untuk lebih tahu dan peduli dengan datadata sejarah yang berada dilingkungan tempat tinggal mereka.

Berdasarkan hasil uraian di atas peneliti akan mengangkat tema stratigrafi sejarah desa Durian Gadis sebagai sumber 
pembelajaran sejarah. Tujuan pada penelitian ini adalah untuk mengetahui strategrafi sejarah di desa Durian Gadis yang dapat dimanfaatkan sebagai sumber pemebelajaran sejarah di Sekolah Menengah Atas Candradimuka Palembang. Dengan demikian penulis akan membahas penelitian ini dengan judul "Stratigrafi desa Durian Gadis sebagai Sumber Pembelajaran Sejarah di Sekolah Menengah Atas Candradimuka Palembang"

\section{B. METODE PENELITIAN}

Metode penelitian yang digunakan oleh peneliti yakni dengan menggunakan metode deskriptif kualitatif. Berdasarkan rumusan masalah, penelitian ini mendeskripsikan secara rinci dan mendalam tentang stratigrafi sejarah desa Durian Gadis sebagai sumber pembelajaran sejarah. Untuk memahami hal tersebut, dilakukan penelitian mendalam mengenai stratigrafi sejarah pada pemukiman masyarakat desa Durian Gadis yang diperkirakan menjadi bagian dari kerajaan Sriwijaya, untuk menjawab pertanyaan permasalahan penelitian yaitu: Bagaimanakah stratigrafi sejarah desa Durian Gadis yang dapat dimanfaatkan sebagai sumber pembelajaran sejarah?

\section{Teknik Pengumpulan Data}

Teknik pengumpulan data adalah suatu cara untuk mendapatkan data yang diperoleh dengan jelas dan buku-buku yang ada kaitannya dengan masalah yang sedang dibahas. Untuk menghimpun datadata yang ada kaitannya dengan masalah ini, sesuai dengan bentuk penelitian kualitatif dan juga jenis sumber data yang dimanfaatkan, maka teknik pengumpulan data yang digunakan dalam penelitian adalah:

\section{Dokumentasi}

Teknik pengumpulan data dengan dokumentasi sebagai pelengkap dari penggunaan metode observasi dan wawancara dalam penelitian kualitatif.
Dokumentasi merupakan catatan peristiwa yang sudah berlalu. Dokumen biasanya berbentuk tulisan, gambar atau karya-karya monumental dari seseorang.Dokumentasi adalah proses pembuktian yang didasarkan atas jenis sumber apapun, baik yang bersifat tulisan, lisan gambaran atau arkeologis (Hugiono dalam Putri, 2015:125). Dalam penelitian ini peneliti mengumpulkan data dengan cara mempelajari dan membaca literatur-literatur yang ada hubungannya dengan objek permasalahan penelitian yaitu data-data di Balai Arkeologi Palembang dan Perpustakaan Universitas PGRI Palembang.

\section{Observasi}

Peneliti melakukan suatu pengamatan langsung pada objek penelitian dan meminta keterangan-keterangan serta mencatat secara sistematis data yang dibutuhkan sehingga dapat diperoleh suatu kesimpulan terhadap objek penelitian tersebut. Observasi pada penelitian ini dilakukan di desa Durian Gadis kecamatan Rambutan kabupaten Banyuasin dan di SMA Candradimuka Palembang.

\section{Wawancara Mendalam}

Wawancara adalah usaha mengumpulkan informasi dengan mengajukan sejumlah pertanyaan secara lisan, untuk dijawab secara lisan pula. Ciri utama dari wawancara adalah kontak langsung dengan tatap muka (face to face relationship) antara si pencari informasi (interviewer atau information hunter) dengan sumber data (Nawawi, 2012:118).

\section{Validitas Data}

Uji keabsahan dalam penelitian, sering hanya ditekankan pada uji validitas data dan reabilitas. Dalam penelitian kualitatif, kriteria utama terhadap data hasil penelitian adalah valid, reliabel dan objektif. Validitas data merupakan ketetapan antara yang terjadi pada objek penelitian dengan data yang dapat dilaporkan peneliti. 


\section{Teknik Analisis Data}

Analisis data yang digunakan dalam penelitian ini ialah analisis model interaktif. Dalam analisis data model interaktif terdiri dari tiga komponen, yaitu: reduksi data, sajian data dan penarikan simpulan/verifikasi (Miles \& Huberman dalam Sutopo, 2002:91). Reduksi data adalah proses seleksi, pemfokusan, penyederhanaan dan abstraksi data dari catatan yang diperoleh di lapangan. Selanjutnya ialah sajian data. Kegiatan analisis yang ketiga adalah menarik kesimpulan dan verifikasi. Analisis data yang dilakukan dalam penelitian ini yaitu menggunakan analisis model interaktif. Analisis model interaktif terdiri atas tiga jalur kegiatan yang terjadi secara bersamaan, yaitu reduksi data, sajian data dan penarikan simpulan/verifikasi.

\section{HASIL DAN PEMBAHASAN Desa Durian Gadis}

Desa Durian Gadis adalah salah satu dari desa yang berada di wilayah kecamatan Rambutan kabupaten Banyuasin provinsi Sumatera Selatan. Secara administratif wilayah desa Durian Gadis sebelah barat berbatasan dengan desa Tanjung Kerang, sebelah timur berbatasan dengan desa Suka Pindah, sebelah selatan berbatasan dengan desa Paritdansebelah utaraberbatasan dengan desa Baru. Desa Durian Gadis berada di dataran rendah yang membentuk sebuah pulau dan dikelilingi oleh kanal-kanal (lebak) (Tim Badan Pemberdayaan Masyarakat dan Pemerintahan Desa Kabupaten Banyuasin, 2015:2).

Menurut kearifan lokal masyarakat setempat bahwa asal kata "Durian Gadis" diambil dari cerita rakyat yang menyatakan "dahulu ada seorang gadis yang meninggal ditimpah oleh buah durian yang jatuh dari pohon". Sehingga daerah yang berada disekitar tempat tersebut diberi nama "DurianGadis" dan nama inipun masih tetap bertahan sampai dengan sekarang (Catatan wawancara no.1, tanggal 31 Januari 2016).

Pola pemukiman masyarakat desa Durian Gadis yang berbaris memanjang mengikuti alur jalan raya yang menghubungkan antara kabupaten Banyuasin dengan Ogan Komering llir. Bangunan rumah dibangun diatas perbukitan, jika dibandingkan dengan daerah-daerah sekitar desa Durian Gadis yang lebih rendah. Menurut pendapat Bapak Heri Setianto, M.Sc. pola pemukiman ini menunjukan bahwa rumah-rumah warga dibangun diatas perbukitan untuk menghindari banjir musiman yang terjadi pada musim penghujan. Melihat pola yang ada, mengindikasikan bahwa rumah-rumah warga desa Durian Gadis saat ini merupakan pemukiman baru (Catatan wawancara no.3, tanggal 31 Januari 2016).

Rumah-rumah warga sebagian besar sudah menggunakan dinding batu bata dengan atap rumah terbuat dari genteng atau semi-permanen. Hanya sebagian kecil rumah dari warga yang masih menggunakan papan atau rumah panggung. Tersedianya jalan yang sudah beraspal memudahkan mobilitas warga untuk beraktifitas dalam rangka memenuhi segala kebutuhan hidupnya. Waktu yang dibutuhkan untuk mencapai desa Durian Gadis dari ibukota provinsi Palembang \pm 1 jam perjalanan dengan jarak tempuh $38 \mathrm{~km}$ menggunakan kendaraan bermotor baik mobil maupun sepeda motor. Sedangkan waktu yang dibutuhkan untuk mencapai ibukota kabupaten yakni Pangkalan Balai \pm 3 jam perjalanan dengan jarak tempuh $45 \mathrm{~km}$. Masyarakat di desa Durian Gadis telah mendapat sambungan aliran listrik dari Perusahaan Listrik Negara (PLN) sehingga alat-alat elektronik sudah banyak digunakan oleh masyarakat sebagai penunjang aktifitas sehari-hari (Tim Badan Pemberdayaan Masyarakat dan Pemerintahan Desa Kabupaten Banyuasin, 2015:2). 


\section{Stratigrafi Desa Durian Gadis}

Lokasi kotak I berada di desa Durian Gadis, dengan posisi GPS (global position system) 0495474-9658914 dan berada di ketinggian $19 \mathrm{~m}$ dpl. Tanah tempat melakukan ekskavasi adalah milik Bapak Duyun dengan usia 45 tahun. Letak kotak I sebelah utara terdapat kebun penduduk, sebelah Barat berbatasan dengan halaman belakang rumah penduduk, sebelah Selatan berbatasan dengan halaman belakang rumah penduduk dan sebelah Timur berbatasan dengan halaman belakang rumah penduduk (Catatan observasi no.3, tanggal 31 Januari 2016).Berdasarkan informasi penduduk setempat memang di desa Durian Gadis ada rumah pesirah (kepala kampung pada masa kesultanan Palembang Darussalam). Oleh karena itu dianggap penting untuk melaksanakan penggalian dengan tujuan untuk mengetahui stratigarfi yang mendukung data sejarah di lokasi tersebut. Penggalian dilakukan dengan sistem spit dengan jarak interval 15 $\mathrm{cm}$ (Catatan observasi no.3, tanggal 31 Januari 2016).

Pada hari pertama dilakukan pembukaan lapisan tanah (ekskavasi) dengan cara melakukan penggalian atau ekskavasi. Kotak 1 dibuka dengan tujuan untuk mengetahui ada atau tidaknya artefakartefak sejarah di dalam tanah, sehingga dapat mendukung data yang ditemukan pada permukaan. Menggunakan spit dengan interval $15 \mathrm{~cm}$. Spit (1) tanah lempung pasiran berwarna coklat. Pada kedalaman 1-10 cm banyak ditemukan sampah dapur hal ini dapat dilihat dari komposisi temuan yang sangat bervariasi seperti, pecahan kaca, fragmen kayu, plastik, fragmen tembikar, batu bata dan pecahan genteng baru milik warga, paku dan sisa-sisa abu pembakaran sampah yang kemudian ditinggalkan (Catatan observasi no.4, tanggal 31 Januari 2016).

Jenis tanah pada kotak penggalian adalah jenis organosol atau tanah gambut. Satuan tanah gambut berasal dari bahan induk bahan organik, biasanya dari hutan rawa atau rumput rawa. Tanah gambut mempunnyai ciri-ciri dan sifat sebagai berikut: tidak terjadi deferensiasi horison secara jelas, ketebalan lebih dari $50 \mathrm{~cm}$, warna coklat kehitaman, tekstur debu sampai lempung, tidak berstruktur, konsistensi tidak lekat sampai agak lekat, kandungan organik lebih dari 30\% untuk tanah tekstur lempung. sedangkan lebih dari $20 \%$ untuk tanah tekstur pasir umunya bersifat sangat asam ( $\mathrm{pH} \mathrm{4,0),} \mathrm{kandungan}$ unsur hara tersedia rendah (Sartohadi. dkk, 2013:115).

Pada kedalaman 10,5-15 cm kondisi tanah lempung tanah berwarna coklat pucat (muda), tekstur terurai, sifat gembur dan partikel halus. Pada lapisan ini baru ditemukan beberapa pecahan tembikar dan keramik. Pertama ditemukan pecahan tembikar pada kedalaman galian $10,5 \mathrm{~cm}$ yang berupa pecahan bibir tembikar dengan diameter $14 \mathrm{~cm}$. Pada kedalaman galian 11 $\mathrm{cm}$ ditemukan pecahan keramik yang berupa pecahan keramik Eropa dengan ketebalan $4 \mathrm{~mm}$. Selanjutnya ditemukan pecahan keramik pada kedalaman galian 12 $\mathrm{cm}$, yang berupa pecahan bibir keramik Cina pada masa dinasti King, dengan ketebalan temuan $4 \mathrm{~mm}$. Di kedalaman galian $15 \mathrm{~cm}$ ditemukan pecahan tembikar yang berupa pecahan dasar tembikar dengan ketebalan 2,6 cm, diameter 9,3 cm dan keliling lingkaran dasar $26 \mathrm{~cm}$ (Catatan observasi no.5, tanggal 31 Januari 2016).

Pada hari kedua dilakukan penggalian lanjutan pada kotak 1 spit ke-2 dengan tujuan untuk mengetahui masih ada atau tidaknya benda-benda yang mengandung data mengenai sejarah di desa Durian Gadis yang berada di dalam tanah. Menggunakan sistem spit dengan interval $15 \mathrm{~cm}$ (16-30 $\mathrm{cm})$. Kondisi tanah sama kondisi tanah lempung berwarna cokelat pucat (muda), tekstur terurai, sifat gembur dan partikel halus. Penggalian sampai dengan kedalaman $30 \mathrm{~cm}$ kemudian penggalian dihentikan. Sebab sudah tidak ada lagi 
benda-benda yang ditemukan mengenai data sejarah desa Durian Gadis (Catatan observasi no.6, tanggal 01 Februari 2016).

Dari barang-barang temuan yang ditemukan baik temuan permukaan maupun temuan pada kotak penggalian I, dapat disimpulkan bahwa desa Durian Gadis telah ditinggali oleh masyarakat sejak masa kerajaan Sriwijaya, Kesultanan Palembang Darussalam, masa kolonial, masa pendudukan Jepang dan tetap berlangsung sampai sekarang (Catatan observasi no.5, tanggal 31 Januari 2016).

\section{Analisis Temuan Data pada Kotak Ekskavasi dan Temuan Lepas (Permukaan)}

Temuan tembikar yang dianalisa adalah temuan di kotak 1 spit $1(1-15 \mathrm{~cm})$ pada kedalaman $15 \mathrm{~cm}$. Pada kotak 1 spit 1 ini ditemukan pecahan dasar tembikar.

Bentuk:pecahan tembikar yang ditemukan merupakan bagian dasar dengan diameter $9,3 \mathrm{~cm}$, tebal bagian dasar $1,9 \mathrm{~cm}$. Berat pecahan dasar tembikar adalah $120 \mathrm{gr}$. Bagian dasar iniberorientasi terbuka dengan fungsi utama memasukan air. Temuan ini merupakan bagian dari guci.

Teknologi: pada bagian dalam tembikar ditemukan bekas striasi yang renggang dan tampak putus-purtus (teknik roda putar lambat). Bahan yang dipakai adalah tanah liat dengan partikel kasar dan tekstur renggang. Pembakaran tembikar berada pada tahap reduksi dengan ditemukan warna hitam yang tidak merata di bagian tengah tembikar. Terdapat slip yang berwarna merah pada bagian dalam gerabah dan warna hitam pada bagian luar. Hiasan pada dasar bagian dalam gerabah dilakukan dengan menggunakan teknik gores/cukil.

Gaya (style): terdapat hiasan bermotif bunga matahari dengan 8 kelopak yang meneglilingi inti. Motif ini berada di dasar bagian dalam tembikar.

Temuan tembikar yang dianalisa adalah temuan di kotak 1 spit $1(1-15 \mathrm{~cm})$.
Temuan tembikar tersebut berada di kedalaman $11 \mathrm{~cm}$, pada kotak 1 spit 1 ini ditemukan pecahan bibir tembikar.

Bentuk: pecahan tembikar yang ditemukan merupakan bagian mulut tembikar dengan diameter $14 \mathrm{~cm}$, tebal $1,2 \mathrm{~cm}$ dan berat 20 gr. Bagian mulut ini beroreintasi terbukadengan fungsi utama memasukan air. Temuan ini diperkirakan merupakan bagian dari Guci.

Teknologi: pada bagian dalam tembikar ditemukan striasi yang renggang dan tampak putus-putus (teknik roda putar lambat). Bahan yang dipakai adalah tanah liat dengan partikel kasar dan tekstur renggang. Pembakaran tembikar berada pada tahap reduksi dengan ditemukan warna hitam yang tidak merata di bagian tengah tembikar. Terdapat slip yang berwarna merah pada bagian dalam gerabah dan warna hitam pada bagian luar. Gaya (style): tidak terdapat hiasan pada pecahan mulut tembikar ini.

Keramik yang dianalisa adalah temuan di kotak 1 spit 1 (kedalaman $1-15 \mathrm{~cm}$ ) ditemukan pada kedalaman $12 \mathrm{~cm}$. Temuan terdiri 2 bagian yang disatukan menjadi bagian bibir dari keramik.

Bentuk: pecahan keramik yang ditemukan merupakan bagian bibir atau mulut keramik. Pecahan mulut keramik memiliki diameter 7 $\mathrm{cm}$, ketebalan $4 \mathrm{~mm}$ dengan berat $4 \mathrm{gr}$. Temuan ini merupakan bagian dari piring.

Teknologi: pada bagian dalam striasi yang padat, halus dan berkesinambunganyang menunjukan penggunaan roda putar cepat. Bahan yang dipakai adalah tanah liat dengan partikel halus dan tekstur rapat. Adonan yang dipakai adalah adonan halus. Bagian dalam berwana putih abu-abu merata yang menunjukan pembakaran pada tahap oksidasi dan vitrifikasi. Glasir dasar keramik berwarna putih, keramik berasal dari Cina pada masa dinasti King.

Gaya (style): terdapat glasir pada kedua sisi keramik, hiasan keramik dengan warna 
polikrom (biru-kehitaman) pembuatan motif dengan teknik tulis.

Keramik yang dianalisa adalah temuan di kotak 1 spit 1 (kedalaman $1-15 \mathrm{~cm}$ ) ditemukan pada kedalaman $10,5 \mathrm{~cm}$. Temuan terdiri 1 bagian yang merupakan bagian dari bibir keramik.

Bentuk: pecahan keramik yang ditemukan merupakan bagian bibir atau mulut keramik. Pecahan mulut keramik memiliki diameter $11 \mathrm{~cm}$, ketebalan $4 \mathrm{~mm}$ denganberat $3 \mathrm{gr}$, kondisi pecahan keramik retak seribu. Temuan ini merupakan bagian dari piring.

Teknologi: pada bagian dalam striasi yang padat, halus dan berkesinambungan yang menunjukan penggunaan roda putar cepat. Bahan yang dipakai adalah tanah liat dengan partikel halus dan tekstur rapat. Adonan yang dipakai adalah adonan halus. Bagian dalam berwana putih abu-abu merata yang menunjukan pembakaran pada tahap oksidasi dan vitrifikasi. Keramik berasal dari Eropa.

Gaya (style): terdapat glasir pada kedua sisi keramik. Warna dasar keramik adalah warna putih, sedangkan warna hiasan menggunakan warna merah hati. Hiasan menggunakan teknik stiker yang bermotif flora.

Temuan keramik yang dianalisa adalah temuan lepas atau temuan permukaan.

Bentuk: pecahan yang ditemukan merupakan bagian dasar keramik dengan tebal $6 \mathrm{~mm}$, dengan diameter $10 \mathrm{~cm}$ dan lingkaran dasar 32,1 cm. Berat temuan 185 gr. Kemungkinan pecahan teko.

Teknologi: pada bagian dalam striasi yang padat, halus dan berkesinambungan yang menunjukan penggunaan roda putar cepat. Bahan yang dipakai adalah tanah liat dengan partikel halus dan tekstur rapat. Adonan yang dipakai adalah adonan halus. Bagian dalam berwana putih abu-abu merata yang menunjukan pembakaran pada tahap oksidasi dan vitrifikasi. Keramik berasal dari Eropa.

Gaya (Style): terdapat logo pabrik yang berlambang singa berkepala manusia dengan posisi duduk. Juga terdapat tulisan "Pstrus Regouts\&Co. MAASTRICHT. MADE IN HOLLAND".

Temuan keramik yang dianalisa adalah temuan lepas pada pemukiman warga.

Bentuk: pecahan yang ditemukan merupakan bagian dasar dengan tebal 4 $\mathrm{mm}$, diameter $4,9 \mathrm{~cm}$, keliling lingkaran 15,3 $\mathrm{cm}$. Berat temuan pecahan $95 \mathrm{gr}$. Temuan ini merupakan pecahan mangkuk.

Teknologi : pada badan bagian dalam terdapat striasi yang padat, halus dan berkesinambungan yang menunjukan penggunaan roda putar cepat. Bahan yang dipakai adalah tanah liat dengan partikel halus dan tekstur rapat. Adonan yang dipakai adalah adonan halus. Bagian dalam keramik berwarna merah dan abu-abu menunjukkan pembakaran dengan oksidasi tahap permulaan. Terdapat bekas tumpangan saat pembakaran pada bagian dalam (spurmark). Keramik temuan ini berasal dari Jepang (Imari).

Gaya (style): terdapat glasir pada kedua sisi keramik dengan warna polikrom (putih-biru). Warna dasar keramik berwarna putih, sedangkan warna hiasan berwarna biru. hiasan pada pecahan mangkuk bermotif geometris.

Temuan keramik yang dianalisa adalah temuan lepas pada pemukiman warga.

Bentuk: pecahan yang ditemukan merupakan bagian dasar dengan diameter $5,9 \mathrm{~cm}$, tebal bagian kaki $3 \mathrm{~mm}$, tebal bagian dasar $4 \mathrm{~mm}$ keliling lingkaran 19,7 $\mathrm{cm}$. Berat temuan pecahan $110 \mathrm{gr}$. Temuan ini merupakan pecahan mangkuk.

Teknologi: pada badan bagian dalam terdapat striasi yang padat, halus dan berkesinambungan yang menunjukan penggunaan roda putar cepat. Bahan yang dipakai adalah tanah liat dengan partikel halus dan tekstur rapat. Adonan yang dipakai adalah adonan halus. Bagian dalam keramik berwarna putih abu-abu menunjukkan pembakaran pada tahap oksidasi dan vitrifikasi. Terdapat bekas tumpangan saat pembakaran pada bagian 
dalam (spurmark). Keramik temuan ini berasal dari dinasti King (1644-1911).

Gaya (style): terdapat glasir pada kedua sisi keramik dengan warna polikrom (putih-biru). Warna dasar keramik berwarna putih, sedangkan warna hiasan berwarna biru. hiasan pada pecahan mangkuk bermotif geometris.

Temuan keramik yang dianalisa adalah temuan lepas pada pemukiman warga.

Bentuk: pecahan yang ditemukan merupakan $1 / 3$ bagian dari mangkuk dengan diameter $12,5 \mathrm{~cm}$, tebal bagian kaki $6 \mathrm{~mm}$, tebal bagian dasar $3 \mathrm{~mm}$. Berat temuan pecahan $105 \mathrm{gr}$. Temuan ini merupakan pecahan mangkuk.

Teknologi: pada badan bagian dalam terdapat striasi yang padat, halus dan berkesinambungan yang menunjukan penggunaan roda putar cepat. Bahan yang dipakai adalah tanah liat dengan partikel halus dan tekstur rapat. Adonan yang dipakai adalah adonan halus. Bagian dalam keramik berwarna merah pucat menunjukkan pembakaran pada tahap oksidasi dan vitrifikasi. Keramik temuan ini berasal dari Cina masa dinasti King (16441911).

Gaya (style): terdapat glasir pada kedua sisi keramik dengan warna monokrom (merah tua). Warna dasar keramik berwarna merah tua, keramik ini tidak memiliki hiasan (polos).

Temuan tembikar yang dianalisa adalah temuan lepas pada pemukiman warga.

Bentuk: pecahan tembikar yang ditemukan adalah bagian badan dengan tebal $2 \mathrm{~mm}$.

Teknologi: pada bagian dalam gerabah ditemukan bekas striasi yang renggang dan tampak putus-putus (teknik roda putar lambat). Bahan yang dipakai adalah tanah liat dengan partikel kasar dan tekstur renggang. Pembakaran tembikar pada tahap reduksi dengan ditemukan warna hitam yang tidak merata di bagian gerabah. Terdapat slip yang berwarna merah pada bagian dalam tembikar dan warna coklat pucat pada bagian luar. Hiasan pada badan tembikar dilakukan dengan menggunakan teknik gores/cukil.

Gaya (Style): terdapat hiasan bermotif garisgaris yang membentuk anyaman pada sisi luar tembikar.

Temuan tembikar yang dianalisa adalah temuan lepas pada pemukiman warga.

Bentuk: pecahan tembikar yang ditemukan adalah bagian mulut dengan diameter 17 $\mathrm{cm}$, tebal bibir bagian bawah $2,2 \mathrm{~cm}$, tebal bibir bagian atas $8 \mathrm{~mm}$. Sedangkan berat pecahan adalah 115 gr. Temuan ini merupakan bagian dari guci.

Teknologi: pada bagian dalam gerabah ditemukan bekas striasi yang renggang dan tampak putus-putus (teknik roda putar lambat). Bahan yang dipakai adalah tanah liat dengan partikel kasar dan tekstur renggang. Pembakaran tembikar pada tahap reduksi dengan ditemukan warna hitam yang tidak merata di bagian gerabah. Terdapat slip yang berwarna merah pada bagian dalam tembikar dan warna coklat pucat pada bagian luar.

Gaya (style): tidak terdapat hiasan pada pecahan mulut tembikar ini.

Temuan tembikar yang dianalisa adalah temuan lepas pada pemukiman warga.

Bentuk: pecahan tembikar yang ditemukan adalah bagian mulut dengan diameter $9 \mathrm{~cm}$, tebal bibir bagian bawah $1,5 \mathrm{~cm}$, tebal bibir bagian atas $7 \mathrm{~mm}$. Sedangkan berat pecahan adalah 65 gr. Temuan ini merupakan bagian dari kendi.

Teknologi: pada bagian dalam gerabah ditemukan bekas striasi yang renggang dan tampak putus-putus (teknik roda putar lambat). Bahan yang dipakai adalah tanah liat dengan partikel kasar dan tekstur renggang. Pembakaran tembikar pada tahap reduksi dengan ditemukan warna hitam yang tidak merata di bagian gerabah. Terdapat slip yang berwarna merah pada bagian dalam tembikar dan warna coklat pucat pada bagian luar. 
Gaya (style): tidak terdapat hiasan pada pecahan mulut tembikar ini.

\section{Pembahasan \\ Nilai Sejarah Stratigrafi Desa Durian Gadis}

Desa Durian Gadis secara geografis merupakan sebuah daratan (pulau) yang di kelilingi oleh rawa-rawa. Rawa-rawa ini mendapat pasokan air dari sungai Sugihan. Sungai telah menjadi bagian tak terpisahkan dari segala aktifitas kehidupan manusia sejak zaman dahulu hingga sekarang. Berdasarkan cerita Bapak Saini, rawa-rawa (lebak) di desa Durian Gadis mengalami kekeringan per 5 bulan dalam setahun sejak tahun 1963 pasca pembangunan bendungan Komering oleh pemerintah dengan tujuan untuk mengairi areal persawahan di daerah Ogan Komering Ulu Timur dan wilayah provinsi Lampung. Hal ini disebabkan, karena 70\% air sungai Komering dialirkan ke daerah propinsi Lampung. Kondisi ini berdampak langsung pada kegiatan masyarakat di desa Durian Gadis yang dulunya menggunakan perahu sebagai alat transportasi, saat ini perahu sama sekali tidak bisa digunakan sebagai alat transportasi untuk memobilisasi manusia maupun hasil pertanian dan perkebunan (Catatan observasi no.1, tanggal 31 Januari 2016).

Sebagai daerah yang dikelilingi oleh sungai, di daerah Durian Gadis masyarakatnya juga mengenal tradisi sonor. Sonor adalah cara menanam padi dengan memanfaatkan musim kering atau kemarau, dengan cara membakar lahan gambut yang kemudian ditanam dengan bibit-bibit padi lokal. Biasanya musim panen akan tiba ketika telah masuk ke musim hujan lebih kurang 6-7 bulan. Namun tradisi sonor hilang ketika pemerintah pada tahun 1995 melarang masyarakat untuk membakar lahan, dengan tujuan untuk menghindari kebakaran yang sangat berdampak bagi ekosistem lingkungan (Catatan observasi no.1, tanggal 31 Januari 2016).
Desa Durian Gadis mempunyai sejarah penting bagi pengembangan sumber pembelajaran sejarah, sebab di daerah ini banyak sekali ditemukan artefakartefak sejarah dan budaya masa lampau sehingga menarik untuk dijadikan sumber pembelajaran sejarah lokal (Catatan observasi no.1, tanggal 31 Januari 2016).

Stratigrafi sejarah merupakan lapisanlapisan tanah pada pemukiman atau bekas pemukiman (pemukiman yang ditinggalkan oleh masyarakat) yang mengandung nilai sejarah sebagai warisan masyarakat terdahulu yang dapat dijadikan sebagai sumber informasi bagi generasi mendatang dalam mengetahui dan memahami peristiwa-peristiwa masa lalu berdasarkan kronologis waktu (Catatan observasi no.1, tanggal 31 Januari 2016). Temuan sejarah di desa Durian Gadis dapat digolongkan, sebagai berikut:

\section{Tinggalan Kerajaan Sriwjaya dan Kesultanaan Palembang Darussalam}

Gambaran kehidupan masyarakat desa Durian Gadis sebelum dibangunnya bendungan Komering oleh pemerintah adalah masyarakat yang menggantungkan hidupnya pada sungai. Melihat beberapa temuan artefak-artefak sejarah baik yang berupa fragmen keramik, fragmen tembikar, kearifan lokal atau floklor yang masih berkembang di masyarakat mengindikasikan bahwa telah berlangsung kehidupan yang cukup lama dan kegiatan manusia pendukung kebudayaan tersebut sezaman dengan berkembangnya kerajaan Sriwijaya dan kemudian dilanjutkan ke masa Kesultanan Palembang Darussalam (Catatan observasi no.2, tanggal 31 Januari 2016).

Sejalan dengan informasi yang didapat dari cerita Bapak Saini (53 tahun) bahwa bukti-bukti arkeologis berupa keramik yang ada di desa Durian Gadis baik yang ditemukan pada permukaan maupun yang ditemukan pada pembukaan kotak ekskavasi 1 yang dilakukan oleh peneliti berhasil menemukan berbagai macam 
keramik Cina dari beberapa periode dinasti yaitu, dinasti Sung yang sezaman dengan kerajaan Sriwijaya dan keramik Cina dari dinasti Ming, Qing yang sezaman dengan Kesultanan Palembang Darussalam. Beberapa jenis fragmen keramik dari Jepang, dan Eropa. Keramik-keramik yang ditemukan memiliki karakter dan motif sendiri-sendiri sesuai dengan masa masyarakat pengguna keramik tersebut (Catatan observasi no.2, tanggal 31 Januari 2016).

Keramik Cina yang ditemukan memiliki motif yang menggunakan teknik tulis langsung pada keramik baik berupa motif ukiran flora maupun fauna. Sedangkan keramik Jepang dan Eropa memiliki hiasan motif flora dan fauna yang menggunakan teknik stiker. Selain itu pada keramik Jepang dan Eropa pada bagian dasar keramik biasanya dilengkapai dengan logo pabrik yang memproduksi keramik tersebut (Catatan observasi no.7, tanggal 31 Januari 2016).

Keramik-keramik yang ditemukan berupa fragmen mangkok, fragmen piring, fragmen teko, fragmen vas bunga. Fragmen keramik tersebut terdiri dari dasar keramik, bibir keramik dan badan keramik yang dari berbagai ukuran. Selain temuan keramik, arftefak-artefak sejarah yang banyak ditemukan di desa Durian Gadis adalah fragmen tembikar. Fragmen tembikar yang ditemukan berupa pecahan guci, tungku, fasu, periuk, vas bunga dan gentong air. Pada umumnya temuan tembikar yang ada di desa Durian Gadis merupakan hasil produksi lokal yang berasal dari daerah Kayu Agung, kabupaten Ogan Komering llir. Tembikar-tembikar ini memiliki hiasanhiasan yang berupa garis-garis. Hiasan pada badan tembikar dilakukan dengan menggunakan teknik gores/cukil ketika benda tersebut maasih basah atau sebelum dilakukan pembakaran dengan cara menggoreskan benda-benda keras seperti logam atau ranting. Fragmen-fragmen tembikar berupa pecahan dasar, pecahan pegangan, pecahan bibir tembikar, pecahan tutup guci dan pecahan badan tembikar (Palembang) (Catatan observasi no.7, tanggal 31 Januari 2016).

Data temuan tersebut dapat diketahui bahwa desa Durian Gadis merupakan salah satu pemukiman lama yang terdapat di pedalaman Sumatera Selatan. Berdasarkan hasil temuan keramik tersebut daerah ini telah menjadi bagian dari wilayah Uluan Kesultanan Palembang Darussalam. Desa Durian Gadis merupakan salah satu pemasok barang-barang dagangan dari pedalaman (Uluan) menuju lliran dengan menggunakan perahu menyusuri sungai Sugihan untuk mencapai ibukota kerajaan yang berada di muara sungai Musi (Palembang) (Catatan observasi no.7, tanggal 31 Januari 2016).

Kesultanan Palembang Darussalam yang berdiri pada abad 17 dan berakhir pada paruh pertama abad 19 dikarenakan kalah perang melawan Belanda. setelah kekalahan perang tersebut Kesultanan Palembang Darussalm dihapuskan oleh Belanda dan digantikan dengan sistem keresidenan (Catatan observasi no.8, tanggal 31 Januari 2016).

Pada Masa Kesultanan Palembang Darussalam desa Durian Gadis juga merupakan salah satu daerah pendukung kedaulatan daulah Islamiah di lliran Palembang. Hal ini dapat dilihat dari aturan hidup masyarakat yang diatur oleh ajaran Islam dan juga diatur oleh undang-undang yang dibuat oleh Kesultanan Palembang yaitu undang-undang simbur cahaya. Undang-undang ini berlaku dan dijalankan oleh daerah-daerah pedalaman (Uluan) yang mengakui kedaulatan Kesultanan Palembang Darussalam. Aturan ini mengatur semua kegiatan hidup masyarakat di pedalaman Sumatera Selatan baik aturan bujang-gadis, adat perhukuman, adat marga, aturan kaum serta aturan dusun dan berladang yang dianjurkan maupun yang dilarang untuk dilakukan (Catatan observasi no.8, tanggal 31 Januari 2016). 
Selain itu dapat dilihat juga pada pemakaman umum desa Durian Gadis telah mendapat pengaruh Islam yang tidak lain dipengaruhi oleh Palembang sebagai ibukota kerajaan Islam di Sumatera Selatan. Pemakaman tidak hanya dilihat tempat sebagai tempat menguburkan orang-orang yang telah meninggal, namun dari makammakam tersebut dapat diperoleh data mengenai perkembangan agama Islam di daerah Durian Gadis. Makam merupakan tempat penghormatan jasad manusia yang berjasa bagi keluarga, desa, marga, suku dan negara. Tokoh dalam kearifan masyarakat desa Durian Gadis berkaitan erat dengan sejarah berdirinya desa dan proses Islamisasi di daerah tersebut. Tokoh sentral tersebut kemudian diabadikan dalam sejarah desa Durian Gadis sebagai sosok puyang desa. Sosok puyang desa digambarakan sebagai sosok yang sakti, memiliki kemampuan lebih dibidang tertentu seperti dibidang agama, pertanian, perikanan, perang, pengobatan (tabib desa) dan sebagainya. Tokoh puyang turut memainkan peran penting di bidang politik, sosial, budaya dan ekonomi di tataran marga dan desa (Catatan observasi no.9, tanggal 01 Februari 2016).

Beberapa nisan dari makam-makam yang ditemukan telah berumur puluhan hingga ratusan tahun, efigrafinya ditulisi dalam huruf Arab Jawi. Nisan-nisan tersebut gaya hiasnya yang sama dengan nisannisan yang ada di komplek pemakaman Kesultanan Palembang Darussalam. Namanama puyang yang dikenal dan dihormati oleh warga masyarakat di desa Durian Gadis, antara lain: (a) Puyang Canggah, (b) Puyang Kakap Panjang. Puyang Kakap Panjang adalah ulama Jawa yang menyebarkan agama Islam di daerah Durian Gadis. Sebab pada abad ke-17 berkembang agama dan tradisi Hindu di daerah ini. (c) Puyang Bangsal, berdasarkan keletakan Global Positioning System(GPS) makam tersebut berada di 0496557-9657298 dengan ketinggian $48 \mathrm{~m}$ dpl, (d) Puyang Ciri
Batu berdasarkan keletakan Global Positioning System (GPS) makam tersebut berada di 0497353-9658929 dengan ketinggian $29 \mathrm{~m}$ dpl. Menurut kearifan lokal setempat puyang Ciri Batu ini memiliki benda pusaka cendikat merah (getang). Kondisi makam ditutupi batu bata, dengan kepala nisan terbuat dari batu (Catatan observasi no.10, tanggal 01 Februari 2016).

Pada masyarakat Durian Gadis ada sebuah tradisi asli bangsa Austronesia yang terus berlangsung dan tetap terjaga sampai sekarang, yakni tradisi berternak kerbau rawa. Kerbau rawa pernah hamper punah pada masa penjajahan Jepang, sebab kerbau-kerbau rawa tersebut banyak digunakan oleh tentara Jepang untuk memenuhi kebutuhan makanan selama berperang untuk menguasai wilayah Indonesia. Ketika Indonesia merdeka, masyarakat memperoleh kembali kebebasannya untuk membuat usaha sesuai dengan kemampuan dan keinginan serta potensi yang ada di lingkungan masyarakat tinggal. Peternakan kerbau rawa kembali dimulai dengan cara mengawinkan kerbau rawa yang berada di daerah Ogan Komering llir dengan kerbau Afrika. Hasil dari perkawinan silang ini menghasilkan kerbau rawa yang memiliki bentuk badan yang berbeda dengan kerbaukerbau rawa yang biasa ditemui di daerahdaerah Sumatera Selatan. Kerbau rawa di desa Durian Gadis memiliki bentuk badan seperti banteng dengan perawakan besar dan memiliki bulu-bulu yang cukup panjang (Catatan wawancara no.4, tanggal 31 Januari 2016).

Hal-hal yang menarik dalam pengembang biakan dan peternakan kerbau air di desa Durian Gadis, antara lain (Catatan wawancara no.4, tanggal 31 Januari 2016):

Satu kelompok padangan kerbau biasanya jumlah anggotanya \pm 80 ekor, hanya ada satu kerbau jantan, apabila lebih dari satu jantan akan menimbulkan masalah perkelahian antara jantan satu dengan 
jantan yang lain akibatnya, yakni pertama nandang (kerbau jantan akan ikut kelompok kerbau lain), kedua adanya sistem penguasaan wilayah padangan.

Salah satu cara yang menarik dalam berternak kerbau rawa, adalah agar kerbau ingat dengan kandangnya. Dengan cara memasukan air yang dicampur dengan garam ke dalam tempurung labu, kemudian tempurung labu tadi digantung di kandang kerbau, nantinya kerbau akan menjilat tempurung labu yang telah diisi air garam. Sehingga kerbau tersebut akan selalu ingat dengan kandangnya.

Penjualan indukan kerbau oleh pemilik harus membayar tebusan tali (denda apabila pemilik mengambil hak dari juru pelihara). Berunding adalah aturan yang tak tertulis namun diakui secara berkelompok dalam pembagian kerbau pertama untuk juru pelihara sedangkan anak kerbau kedua untuk pemilik.

Apabila nazar pemilik kerbau tercapai, maka pemilik kerbau akan memberikan seekor kerbau kepada masyarakat untuk dipotong pada saat hari raya idul fitri dan dibagi-bagikan kepada warga masyarakat di desa Durian Gadis.

\section{Tinggalan Sejarah Bangsa Eropa}

Tinggalan-tinggalan arkeologis dari bangsa-bangsa Eropa yang ditemukan di desa Durian Gadis berupa pecahan keramik Eropa baik yang berbentuk piring kangkung, teko dan vas bunga. Temuan-temuan keramik Eropa berupa pecahan dasar, pecahan bibir keramik dan badan keramik. Biasanya hiasan-hiasan yang ditemukan pada keramik-keramik Eropa berupa gambaran kegiatan manusia sehari-hari, gambar hewan dan bunga-bunga. Hiasanhiasan pada keramik Eropa menggunakan teknik stiker, serta setiap hasil produk keramik Eropa biasanya disertai dengan logo atau merek pabrik yang memproduksi (Catatan observasi no.11, tanggal 01 Februari 2016).
Tinggalan-tinggalan bangsa Eropa khususnya Belanda yang masih tetap lestari di kehidupan masyarakat adalah perkebunan karet. Perkebunan karet mulai diperkenalkan oleh pemerintah kolonial Belanda di Sumatera Selatan pada awal abad ke-20. Dengan adanya perkebunan karet perekonomian masyarakat di Sumatera Selatan mengalami perkembangan yang pesat, mengingat pada awal abad ke-20 permintaan getah karet sangat tinggi dipasaran internasional. Salah satu wilayah yang mampu memenuhi kebutuhan pasar tersebut adalah daerah Sumatera Selatan. Di desa Durian Gadis perkebunan karet dimulai pada tahun 1910 , dimana masyarakat setempat menanam tanaman karet alam dengan cara menanam biji. Hasil getah karet di jual dengan tokehtoke Cina yang ada di Palembang menggunakan perahu melalui jalur sungai Sugihan (Catatan observasi no.12, tanggal 01 Januari 2016).

Interaksi yang terjadi antara lliran dan Uluan melalui proses perdagangan inilah akan terjadi penawaran produk-produk lokal dengan barang-barang hasil pabrikan bangsa-bangsa Eropa. Kegiatan ini memberikan informasi bahwa desa Durian Gadis menjadi salah satu daerah yang mengkonsumsi produk-produk kolonial, terutama golongan-golongan elit masyarakat tradisional Indonesia seperti pesirah, ketua adat (khetib) dan orang-orang pribumi yang bekerja di perusahaan bangsa-bangsa Eropa (Catatan observasi no.13, tanggal 01 Februari 2016).

\section{Tinggalan Sejarah Penjajahan Jepang}

Tinggalan-tinggalan arkeologis yang berasal dari negeri Jepang juga ditemukan di desa Durian Gadis. Temuan-temuan keramik Jepang yang berupa pecahan piring Imari dengan warna dasar berglasir putih dengan hiasan bermotif meander berwarna biru. Temuan ini menunjukan bahwa Jepang telah masuk ke wilayah Nusantara jauh sebelum perang dunia ke-II. Jepang telah 
lama menjalin hubungan dengan para pedagang dan penguasa pribumi termasuk di pedalaman Sumatera Selatan (Uluan), Ini menunjukan bahwa desa Durian Gadis memiliki peran yang cukup penting dalam dunia perdagangan di wilayah pedalaman Sumatera Selatan (Catatan observasi no.14, tanggal 01 Februari 2016).

Pada tahun 1942 ketika Jepang berhasil mengalahkan bangsa Belanda yang berkuasa di Indonesia. Desa Durian Gadis menjadi salah satu basis dari tentara Jepang di wilayah Sumatera Selatan. Menurut keterangan bapak Saini, ada salah satu tempat di desa Durian Gadis yang dikenal dengan sebutan "Simpang Nippon", tempat ini menjadi cam tentara untuk membuat lapangan terbang Jepang, hal ini dibuktikan dengan adanya sisa bangunan dapur umum tentara Jepang. Dalam upaya mewujudkan keinginan tersebut, maka dikirimlah tenaga-tenaga kerja paksa (romusha) oleh tentara Jepang. Dapur umum ini digunakan sebagai tempat memasak kebutuhan makanan tentara yang berencana menjadikan desa Durian Gadis sebagai tempat bandar udara Jepang (Catatan wawancara no.3, tanggal 31 Januari 2016). Namun keinginan ini gagal terwujud pada tahun 1945 karena kegagalan Jepang dalam perang dunia ke-II (Catatan observasi no. 15, tanggal Februari 2016).

\section{Stratigarfi Desa Durian Gadis}

Menurut Bapak Ka'ap Djalili, S.Sos., M.Si., untuk menjadikan stratigrafi sejarah di desa Durian Gadis sebagai sumber pembelajaran sejarah lokal. Kriteria pokok hasil penelitian sejarah yang wajib dipenuhi untuk menjadi sumber pembelajaran sejarah di sekolah. Sumber pembelajaran yang akan dipilih oleh guru sejarah sesuai dan dapat menunjang pencapaian standar kompetensi dan kompetensi dasa, setelah itu sumber pembelajaran sejarah dapat dimanfatkan dalam pembelajaran. Materi tentang stratigrafi sejarah di desa Durian Gadis sebagai sumber pembelajaran sejarah termasuk pada (Catatan wawancara no.9, tanggal 11 Mei 2016): Standar Kompetensi: 1. Menganalisis Perjalanan Bangsa Indonesia pada Masa Negara-negara Tradisional. Kompetensi Dasar: 1.3. Menganalisis pengaruh perkembangan agama dan kebudayaan Islam terhadap masyarakat di berbagai daerah di Indonesia. Materi Pembelajaran: contoh perkembangan Islam di berbagai daerah dari abad ke-15 sampai abad ke-18 dan kehidupan sosial, politik, ekonomi, dan budaya Islam di Indonesia (Catatan wawancara no.9, tanggal 11 Mei 2016). Jadi materi tentang stratigrafi sejarah desa Durian Gadis sebagai sumber pembelajaran sejarah lokal dapat diajarakan di kelas XI IPS semester 1. Materi tentang stratigrafi sejarah desa Durian Gadis dapat dikembangkan dalam proses pembelajaran karena materi stratigrafi sejarah desa Durian Gadis merupakan bagian dari sejarah lokal yang harus diperkenalkan kepada siswa, sebagai upaya menumbuhkan rasa afeksi siswa terhadap daerahnya sendiri (Catatan observasi no.17, tanggal 12 Mei 2016).

Dari hasil wawancara peneliti dengan guru sejarah SMA Candradimuka Palembang dapat diketahui bahwa ia memberikan apresiasi yang tinggi dengan penelitian ini, sebab sangat jarang ada sumber pembelajaran sejarah yang mengangkat nilai-nilai kelokalan. Bagi Bapak Ka'ap Djalili, S.Sos., M.Si. materi tentang stratigarfi sejarah desa Durian Gadis sebagai sumber pembelajaran sejarah sangat menambah wawasan pengetahuan, menumbuhkan rasa afeksi, bisa melestarikan kebudayaan suatu daerah serta melestarikan sejarah daerah sebagai kebanggaan dan menjadi identitas bagi daerah itu sendiri. Beliau berharap nantinya, ketika materi mengenai stratigrafi sejarah desa Durian Gadis benar-benar dijadikan sebagai sumber pembelajaran sejarah lokal Sumatera Selatan, akan menambah khazanah pengetahuan bagi siswa khususnya di SMA Candradimuka 
Palembang tentang sejarah daerah-daerah Sumatera Selatan umumnya dan sejarah daerah mereka sendiri pada khususnya sebagai upaya menambahkan rasa kecintaan terhadap daerah (Catatan wawancara no.11, tanggal 11 Mei 2016).

\section{SIMPULAN}

Berdasarkan hasil penelitian dan pembahasan dapat disimpulkan bahwa:

1. Situs desa Durian Gadis adalah salah satu peninggalan leluhur masyarakat desa Durian Gadis, yang sangat kaya akan data-data arkeologi dari masa kerajaan Sriwijaya, Kesultanan Palembang Darussalam sampai dengan masa-masa kolonial.

2. Data arkeologi di desa Durian Gadis harus segera diselamatkan, mengingat data-data ini berada di pemukiman warga yang sangat rentan akan tergusur dan hilang seiring dengan terus dilakukannya pembangunan rumah warga.

3. Peluang masih sangat terbuka untuk menyelamatkan dan mengawetkan data-data sejarah desa Durian Gadis dengan melakukan penelitian ilmiah, mempublikasikan melalui surat kabar dan penerbitan buku-buku dari hasil penelitian mengenai data-data tersebut.

4. Nilai sejarah dari stratigrafi desa Durian Gadis dapat dijadikan sebagai sumber pembelajaran sejarah lokal di sekolahsekolah.

\section{DAFTAR PUSTAKA}

Badan Pusat Statistik dan BAPPEDA Kabupaten Banyuasin. 2012. Banyuasin dalam Angka/Banyuasin in
Figures 2012. Badan Pusat Statistik dan BAPPEDA Kabupaten Banyuasin.

Departemen Pendidikan dan Kebudayaan. 1991. Kamus Besar Bahasa Indonesa:

Edisi Kedua. Jakarta: Balai Pustaka.

Hamalik, Oemar. 2014. Kurikulum dan Pembelajaran. Jakarta: Bumi Aksara.

Nawawi, Hadari. 2012. Metode Penelitian Bidang Sosial. Yogyakarta: Gadjah Mada University Press.

Rangkuti, Nurhadi. 2007. Tabir Peradaban Sungai Lematang: Balai Arkeologi Palembang.

Pranoto, Suhartono W. 2012. Teori \& Metodologi Sejarah. Yogyakarta: Graha IImu.

Priyadi, Sugeng. 2012. Metode Penelitian Pendidikan Sejarah. Yogyakarta: Ombak.

Putri, Yenda Fera Mesta dan Aan Suriadi. 2015. Jurnal Sejarah dan Pembelajaran Sejarah Volume 1, Nomor 2, Desember 2015 "Kalpataru", Situs Puyang Mulia Sakti di Desa Penanggiran sebagai Materi Pengayaan Pembelajaran Sejarah Lokal di Kelas VII SMP Negeri 2 Ujan Mas kabupaten Muara Enim. Program Studi Pendidikan Sejarah Jurusan Pendidikan IImu Pengetahuan Sosial Fakultas Keguruan dan IImu Pendidikan Universitas Persatuan Guru Republik Indonesia Palembang.

Sutopo, H.B. 2002. Metodologi Penelitian Kualitatif Dasar Teori dan Terapannya dalam Penelitian. Surakarta: Sebelas Maret University Press. 